\title{
Improved dissolution and micromeritic properties of naproxen from spherical agglomerates: preparation, in vitro and in vivo characterization
}

\author{
Damineni Saritha ${ }^{1^{*}}$, Penjuri Subhash Chandra Bose ${ }^{2}$, Poreddy Srikanth Reddy², \\ Grandhi Madhuri ${ }^{3}$, Ravouru Nagaraju ${ }^{3}$ \\ ${ }^{1}$ Department of Pharmaceutics, Sultan-ul-uloom College of Pharmacy, Hyderabad, India, ${ }^{2}$ Department of Pharmaceutics, \\ MNR College of Pharmacy, Sagareddy, India, ${ }^{3}$ Institute of Pharmaceutical Technology, Sri Padmavathi Mahila Visva Vidyalayam, \\ Tirupathi, India
}

\begin{abstract}
Naproxen, an anti-inflammatory drug, exhibits poor aqueous solubility, which limits the pharmacological effects. The present work was carried out to study the effect of agglomeration on micromeritic properties and dissolution. Naproxen agglomerates were prepared by using a three solvents system composed of acetone (good solvent), water (non-solvent) and dichloromethane (bridging liquid). Differential Scanning Calorimetry (DSC) results showed no change in the drug after crystallization process. X-Ray Powder Diffraction (XRPD) studies showed the sharp peaks are present in the diffractograms of spherical agglomerates with minor reduction in height of the peaks. The residual solvents are largely below the tolerated limits in the agglomerates. Scanning Electronic Microscopy (SEM) studies showed that agglomerates were spherical in structure and formed by cluster of small crystals. The agglomerates exhibited improved solubility, dissolution rate and micromeritic properties compared to pure drug. Anti-inflammatory studies were conducted in Wistar strain male albino rats and naproxen agglomerates showed more significant activity than the pure drug.
\end{abstract}

Uniterms: Naproxen/micromeritic properties. Naproxen/spherical agglomerates/dissolution. Residual solvents. Ulcerogenic potential. Bridging liquid.

\begin{abstract}
Naproxeno, fármaco anti-inflamatório, apresenta baixa solubilidade em água, o que limita os efeitos farmacológicos. O presente trabalho foi realizado para estudar o efeito da aglomeração nas propriedades micromeríticas e na dissolução. Aglomerados de naproxeno foram preparados por meio da utilização de sistema de três solventes composto de acetona (bom solvente), água (não-solvente) e diclorometano (líquido de ligação). A DSC não resulta mostrou nenhuma mudança na droga depois de processo de cristalização. Estudos de difração de Raios X do Pó (XRPD) mostraram picos agudos nos difratogramas de aglomerados esféricos, com redução mínima dea altura dos picos. Os solventes residuais estão amplamente abaixo dos limites tolerados nos aglomerados. Os estudos de Microscopia Eletrônica de Varredura (SEM) mostraram que esses aglomerados eram de estrutura esférica e formados por grupos de pequenos cristais. Os aglomerados apresentaram solubilidade, taxa de dissolução e propriedades micromeríticas aprimoradas em comparação com o fármaco puro. Estudos anti-inflamatórios foram conduzidos em ratos Wistar albinos masculinos e os aglomerados de naproxeno mostraram atividade mais significativa do que o fármaco puro.
\end{abstract}

Unitermos: Naproxeno/propriedades micromeríticas. Naproxeno/aglomerados esféricos/dissolução. Solventes residuais. Potencial ulcerogênico. Líquido de ligação.

*Correspondence: D. Saritha. Department of Pharmaceutics, Sultan-ul-uloom College of Pharmacy, Road No: 3, Banjara Hills, Hyderabad, Andhra Pradesh, India. E-mail: daminenisaritha@yahoo.co.in 


\section{INTRODUCTION}

Recently the direct tablet compression method is frequently and preferably used for tablet manufacturing, since many processing steps (granulation, drying etc) are eliminated and in addition wet technology can not be used to moisture sensitivity agents (effervescent tablets) (Maghsoodi et al., 2007). In the direct tabletting method, it is necessary to increase the flowability and compressibility of the bulk powder in order to retain a steady supply of powder mixture to the tabletting machine and sufficient mechanical strength of the compacted tablet. In addition to increasing the efficiency of the manufacturing process it is also important to increase bioavailability of the drug by improving the solubility of the bulk drug powder. Spherical agglomeration is a novel method to increase the bioavailability of the drug that inherently has poor aqueous solubility. It is a multiple unit process in which crystallization, agglomeration and spheronization can be carried out simultaneously in one step (Kulkarni et al., 2002). The resultant crystals have characteristic shape which dramatically improved the micromeritic properties such as flowability, packability and compressibility so that direct tabletting or coating is possible without further processing (mixing, agglomeration, sieving).

Spherical agglomeration is a process of formation of aggregates of crystals held together by liquid bridges. The agglomerates are formed by agitating the crystals in a liquid suspension in presence of binding agent. The bridging liquid should be immiscible in the suspending medium, but capable of cementing the particles to be agglomerated. This technique can also be exploited to increase solubility, dissolution and hence bioavailability of poorly soluble drugs (Di Martino, 1999; Sano, 1987; Kawashima et al., 1990). These modifications allow for the practice of more efficient manufacturing methods that could save time and reduces economic risk.

Naproxen is an anti-inflammatory drug which exhibits poor water solubility and unsuitable for direct tabletting due to its poorly compressible properties, although strongly demanded in commercial production by direct tabletting. It exhibits poor flow, and a high tendency of adhesion. To improve the micromeritic properties, dissolution rate and bioavailability, spherical crystallization method is attempted.

\section{MATERIAL AND METHODS}

Naproxen was kindly provided by Divis labs, Hyderabad, India. Acetone and dichloromethane were purchased from Merck, Mumbai, India. All chemicals and buffers used were of analytical grade.

\section{Selection of solvent proportions for spherical agglomeration}

Ternary phase diagram of acetone, dichloromethane and water was constructed to select a suitable zone with appropriate ratio of three solvents for the preparation of spherical agglomerates.

\section{Preparation of spherical agglomerates of naproxen}

For spherical agglomeration of naproxen acetone was found to be suitable solvent due to its excellent solubility and miscibility with dispersing water phase (poor solvent). Dichloromethane was chosen as bridging liquids because of its good wettability with the drug. Naproxen $5 \mathrm{~g}$ was dissolved in $25 \mathrm{~mL}$ of acetone at $45^{\circ} \mathrm{C}$ until a clear solution was obtained. Drug solution was poured quickly in to $62.5 \mathrm{~mL}$ of water maintained at $20^{\circ} \mathrm{C}$, under continuous stirring at $500 \mathrm{rpm}$ with a propeller type agitator. When fine crystals of naproxen begin to precipitate ( 5 $\mathrm{min}), 12.5 \mathrm{~mL}$ of dichloromethane was added slowly drop wise, followed by $30 \mathrm{~min}$ stirring. Agglomerates obtained were separated from the solution by filtration and dried at $60{ }^{\circ} \mathrm{C}$ for 6 hours in an oven. The dried agglomerates were then stored in screw-capped jar in a desiccator.

\section{Drug content}

Spherical agglomerates $(50 \mathrm{mg})$ were triturated with $10 \mathrm{~mL}$ of water. Allowed to stand for $10 \mathrm{~min}$ with occasional swirling and methanol was added to produce 100 $\mathrm{ml} .5 \mathrm{ml}$ of this solution was mixed with equal volumes of methanol and phosphate buffer $\mathrm{pH} 7.4$ to produce 100 $\mathrm{mL}$. Absorbance of the resulting solution was measured at $234 \mathrm{~nm}[6]$.

\section{Melting point}

Melting point of naproxen crystals was determined by placing the drug filled capillary tubes in digital melting point apparatus (Polmon, Hyderabad, India). Melting point was noted and compared with the pure drug.

\section{Differential Scanning Calorimetry (DSC)}

To detect possible polymorphic transition during the agglomeration process, DSC studies were carried out by using differential scanning calorimeter (DSC 60, Shimadzu, Japan) with DuPont 9900 thermal analyzer. All accurately weighed samples (about $1 \mathrm{mg}$ of naproxen or its 
equivalent) were placed in sealed aluminum pans, before heating under nitrogen flow $(20 \mathrm{~mL} / \mathrm{min})$ at a scanning rate of $10{ }^{\circ} \mathrm{C} \mathrm{min}{ }^{-1}$, from $25^{\circ} \mathrm{C}$ to $250{ }^{\circ} \mathrm{C}$. An empty aluminum pan was used as reference.

\section{X-ray analysis}

X-Ray powder diffraction patterns were used to detect possible polymorphic transition during the crystallization process. X-Ray powder diffraction patterns were obtained at room temperature using X' Pert MPD diffractometer (Philips, Holland), with $\mathrm{Cu}$ as anode material and graphite monochromator, operated at a voltage of $40 \mathrm{~mA}$, $45 \mathrm{kV}$. The samples were analyzed in the $2 \theta$ angle range of 3-50 and the process parameters used were set as scan step size of $0.0170(2 \theta)$, scan step time of $51.0362 \mathrm{sec}$ and time of acquisition of $1 \mathrm{~h} .2 \theta$ values were processed using multidimensional minimization programme to calculate cell volume, cell parameters and space grouping.

\section{Scanning electron microscopy}

The Scanning electron microscopic (Joel- LV-5600, USA, with magnification of $250 \mathrm{X}$ ) photographs were obtained to identify and confirm spherical nature and morphological characters of the agglomerates.

\section{Surface topography}

Tracings of spherical agglomerates were taken using Camera Lucida fixed to optical microscope (magnification $45 \mathrm{X}$ ) (Paradkar et al., 2002) and were used to calculate circulatory factor $(\mathrm{S})$ as $\mathrm{S}=\mathrm{P}^{2} /(12.56 \mathrm{XA})$, where $\mathrm{A}$ is area $\left(\mathrm{cm}^{2}\right)$ and $\mathrm{P}$ is perimeter $(\mathrm{cm})$.

\section{Micromeritic properties}

Particle size of pure drug was determined by microscopic method using calibrated ocular micrometer and size of spherical agglomerates was determined by sieving method [8]. Apparent particle densities of agglomerated and pure drug were measured using a Pycnometer (Gay Lussac, India). Carr's index was determined from powder volumes at the initial stage and after 1250 tappings to constant volume (Electrolab, Mumbai). The angle of repose of agglomerated and pure drug was measured by fixed funnel method.

\section{Crushing strength}

Crushing strength of agglomerates was determined using modified Jarosz and Parrot's mercury load cell method (Paradkar et al., 2002). It was carried out using a $10 \mathrm{~mL}$ glass hypodermic syringe. The modifications include removal of the tip of the syringe and the top end of the plunger. The barrel was used as a hollow support and guide tube with close fitting to the plunger. A window was cut at the lower end of the barrel to facilitate placement of the agglomerate on the base platen. The plunger acted as a movable platen. It was set directly on the agglomerate, positioned on the lower platen. Mercury was added to the plunger at a rate of $10 \mathrm{~g} / \mathrm{sec}$ from a separating funnel, from a fixed height. The total weight of mercury plus that of plunger required to break the agglomerate was the crushing strength $(\mathrm{g})$.

\section{Determination of residual solvents concentration}

Residual water in spherical agglomerates was determined using Karl Fischer (Polmon, Hyderabad, India) titrimeter, calibrated with sodium tartrate. Gas chromatography (Shimadzu GC-14B chromatograph, Japan) was used to estimate residual Acetone and dichloromethane in spherical agglomerates (Piera Di Martino et al., 2000).

\section{Solubility studies}

The solubility of naproxen spherical agglomerates in water was determined by taking excess quantity of spherical agglomerates into screw- capped $50 \mathrm{~mL}$ glass vials. The vials were shaken for two hours on mechanical shaker (Nocent et al., 2001). The solution was filtered and analysed for drug content spectrophotometrically at $234 \mathrm{~nm}$.

\section{Dissolution studies of agglomerates}

The dissolution of naproxen pure drug and spherical agglomerates sample was determined by using USP dissolution apparatus XXIV-Type II (Electro Lab, Mumbai, India). The dissolution medium used was $900 \mathrm{ml}$ of phosphate buffer ( $\mathrm{pH}$ 7.4).

The $5 \mathrm{~mL}$ of sample solutions were withdrawn at predetermined time intervals and then filtered. A volume of $5 \mathrm{~mL}$ of phosphate buffer ( $\mathrm{pH} 7.4$ ) was replaced in the dissolution flask to maintain volume constant. The amount of dissolved naproxen in the sample solutions was analyzed spectrophotometrically at $234 \mathrm{~nm}$.

\section{In vivo evaluation of agglomerates}

The naproxen agglomerates obtained were subjected to in vivo studies to assess their anti-inflammatory activity 
and to screen for ulcerogenic potential, the major adverse effect caused by the naproxen.

\section{Evaluation of anti-inflammatory activity}

The anti-inflammatory activity of prepared naproxen agglomerates was evaluated by the carrageenan-induced rat hind paw edema method (Rao et al., 1994). The experimental protocol was designed and approval of Institutional Animal Ethics Committee (IAEC) (Reg. No. 557/02/c/ CPCSEA) was obtained. Wistar strain male albino rats weighing between (150-200 g) were used. The animals were in a light controlled 12 hours cycle with free access to food and water. Animals were fasted overnight before experiment with free access to water (Lichtenberger $e t$ al., 2009). Anti-inflammatory activity of the naproxen agglomerates was compared to the pure naproxen drug. Animals were divided into three groups of six animals each. Group I (control I) received water. Group II, (standard) received $25 \mathrm{mg} / \mathrm{kg}$ pure naproxen and Group III received 25 $\mathrm{mg} / \mathrm{kg}$ naproxen agglomerates. After one hour, paw edema was induced by injecting $50 \mu \mathrm{L}$ of $1 \% \mathrm{w} / \mathrm{v}$ carrageenan into the sub planar region of the left hind paw. Paw volume was determined after five hour in all groups. Difference in the paw volume, determined before and after injection of the edema-provoking agent indicated the severity of edema. One control group and reference group were used in this study. Volumes of right hind paw of controls and treated animals were measured with a plethysmometer and the percentage inhibition of inflammatory reaction was determined for each animal by comparison with control and calculated by the following formula.

$$
\% \text { inhibition of edema }=\frac{\left(\mathrm{V}_{\text {Control }}-\mathrm{V}_{\text {test }}\right)}{\mathrm{V}_{\text {Control }}} \times 100
$$

where, $\mathrm{V}_{\text {control }}=$ mean edema of rats in control group; $\mathrm{V}_{\text {test }}$ $=$ mean edema volume of rats in tested group

\section{Assessment of ulcerogenic potential of naproxen agglomerates}

Healthy Wistar strain male albino rats weighing between $150-200 \mathrm{~g}$ were used for the study and individually maintained under standard conditions $(12 \mathrm{~h}$ light and dark cycles, $25 \pm 22{ }^{\circ} \mathrm{C}$ and $35-60 \%$ humidity). The rats were fed with animal fed pellets and had free access to water.

The rats were divided into three groups each containing 6 animals that are controlled (group-1), standard (group-2) and test group (group-3). Animals were kept under fasting with free access to water for $48 \mathrm{~h}$ before test. Group 1 received plain water, Group 2 received pure naproxen $(25 \mathrm{mg} / \mathrm{kg})$ and Group 3 received naproxen agglomerates $(25 \mathrm{mg} / \mathrm{kg})$ and was sacrificed after $6 \mathrm{~h}$ (Veerapur et al., 2004). Their stomachs were isolated and opened along the greater curvature, the mucosa was washed under slow running tap water and the number and size of ulceration was scored as per the method (Rao et al., 1994). The contents were centrifuged at $3000 \mathrm{rpm}$ for 10 min. Total acidity and $\mathrm{pH}$ was analyzed from the decanted supernatant by using broad range $\mathrm{pH}$ paper.

\section{Ulcer index}

The washed stomach was fixed on a cork plate and the number and severity of the ulcers were measured using the scores (Kulkarni, 2002).

Severity Score:

$0=$ Normal colored stomach

$0.5=$ Red coloration

$1=$ Spot ulcer

$1.5=$ Hemorrhagic streaks

$2=$ Ulcers $\geq 3$ but $\leq 5$

$3=$ Ulcers $>5$.

\section{RESULTS AND DISCUSSION}

\section{Selection of solvent proportions for spherical agglomeration}

Spherical agglomerates of naproxen were prepared by simple agglomeration technique using a three solvent system. It involves a good solvent, a poor solvent and bridging liquid. Selection of these solvents depends on miscibility of the solvents and the solubility of the drug in individual solvents. Accordingly different combinations were tried by ternary phase diagram to produce optimum solvent system (Di Martino et al., 2000). The drug solubility and mutual miscibility of solvent systems are examined. Acetone, water and dichloromethane were selected as solvent system.

Acetone is miscible with water and dichloromethane. The ternary diagram is envisaged, to select the solvent composition. The points on the vertex correspond to a pure liquid; those on the sides correspond to a mixture of only two liquids. Since the presence of three liquids is necessary (good solvent, bridging solvent and poor solvent) for spherical agglomeration, points on the sides of the triangle are excluded. 36 points remain for experiment. Each triangle in the ternary diagram was investigated for the agglomeration. The optimal ratio for spherical agglomeration was selected as 25:62.5:12.5. 


\section{Preparation of spherical agglomerates of naproxen}

The proportions of acetone/water/dichloromethane were chosen for the study is $25 / 62.5 / 12.5 \mathrm{~mL}$ respectively. Agglomerates were formed by agitating the crystals in a liquid suspension and adding a bridging liquid, which preferentially wets the crystal surface to cause binding. The addition of bridging liquid (dichloromethane) promotes the formation of liquid bridges between the drug crystals to form agglomerates.

To optimize naproxen spherical agglomeration by acetone/water/dichloromethane system, other process parameters were considered such as amount and mode of addition of bridging liquid, stirring speed and time, temperature.

The average diameter of agglomerates was found to increase with increasing amount of dichloromethane in the agglomeration medium due to excessive bridging liquid on the surface for coalescence.

Size of agglomerates is very much dependent on the degree of agitation. Due to agitation droplets will be formed in the agglomeration medium and it induces movement of droplets from in to out. The intensity of this internal circulation depends on the speed. At lower stirring rate $(<400 \mathrm{r} / \mathrm{min})$ reduces the possibility of obtaining agglomerates due to slow circulation of the droplets in the medium and slight collision between the droplets. At optimum speed (500 r/min) more compact and dense agglomerates were obtained. Higher speed ( $>600 \mathrm{r} / \mathrm{min}$ ) induces agglomerate destruction due to more impact energy for collision due to increased turbulence resulting in formation of agglomerates with irregular shape.

The temperature of solvent system was found to have pronounced effect on the process of agglomeration. Agglomeration was not observed when the process was carried out at $10 \pm 3^{\circ} \mathrm{C}$. It could be due to reduced solubility of drug in the solvent system. When the temperature was increased to $45 \pm 3{ }^{\circ} \mathrm{C}$ very large agglomerates were produced due to enhanced solubility (Saturation of the drug in the medium). Optimum agglomeration was achieved at $20 \pm 3{ }^{\circ} \mathrm{C}$ due to optimum solubility of the drug.

Addition of bridging liquid plays vital role in formation off agglomerates. When the bridging liquid was added at a time agglomerates were of irregular geometry which may be due to its localization and hence its unavailability for efficient agglomeration. Drop wise addition with continuous agitation resulted in agglomerates of regular geometry which can be attributed to uniform distribution of bridging liquid.

\section{Drug content}

The drug content obtained was in the range of $99.12 \pm 1.54 \%$.

\section{Melting point}

The melting point of naproxen pure drug and agglomerates was found to be in the range $150{ }^{\circ} \mathrm{C}-155^{\circ} \mathrm{C}$ and was observed that there was no change in melting points of pure drug and agglomerates. Thus, formation of polymorphs was over ruled, as crystal habit will not change the melting point.

\section{Differential scanning calorimetry (DSC)}

DSC thermograms of pure and naproxen agglomerates are illustrated in Figure 1. The DSC pattern of pure naproxen and agglomerates showed a sharp endothermic peak at $153^{\circ} \mathrm{C}$ corresponding to its melting point. Sharp melting point with flat base line, which indicated that the material was not affected by hydration, solvation, polymorphic transition and in addition there was no interaction of drug with solvents.

\section{X-ray analysis}

X-Ray powder diffraction (XRD) is a powerful technique for the identification of crystalline solid phase. Every crystalline solid phase has a unique XRD pattern, which can form the basis for its identification. XRD pattern in $2 \theta$ range showed the diffraction peaks, characteristic of naproxen in both pure and agglomerate forms Figure 2 , suggesting that crystallization did not cause any structural modifications. The slight differences in the relative intensities of their peaks at the respective $2 \theta$ values may be attributed to differences in the particle size or crystallinity of the sample. The disappearance of peaks in naproxen agglomerates at $32^{\circ}$ and $46^{\circ}$ was due to the markedly different crystal habits. Therefore the relative abundance of the planes exposed to the X-ray source would have been altered, producing the disappearance of peaks or variations in the relative intensities of the peak.

XPRD spectral data of pure naproxen and spherical agglomerates were showed similar peaks indicating that there was no structural alteration occurred due to the technique employed for preparing spherical agglomerates.

\section{Scanning electron microscopy}

The surface morphology and shape of the agglomer- 


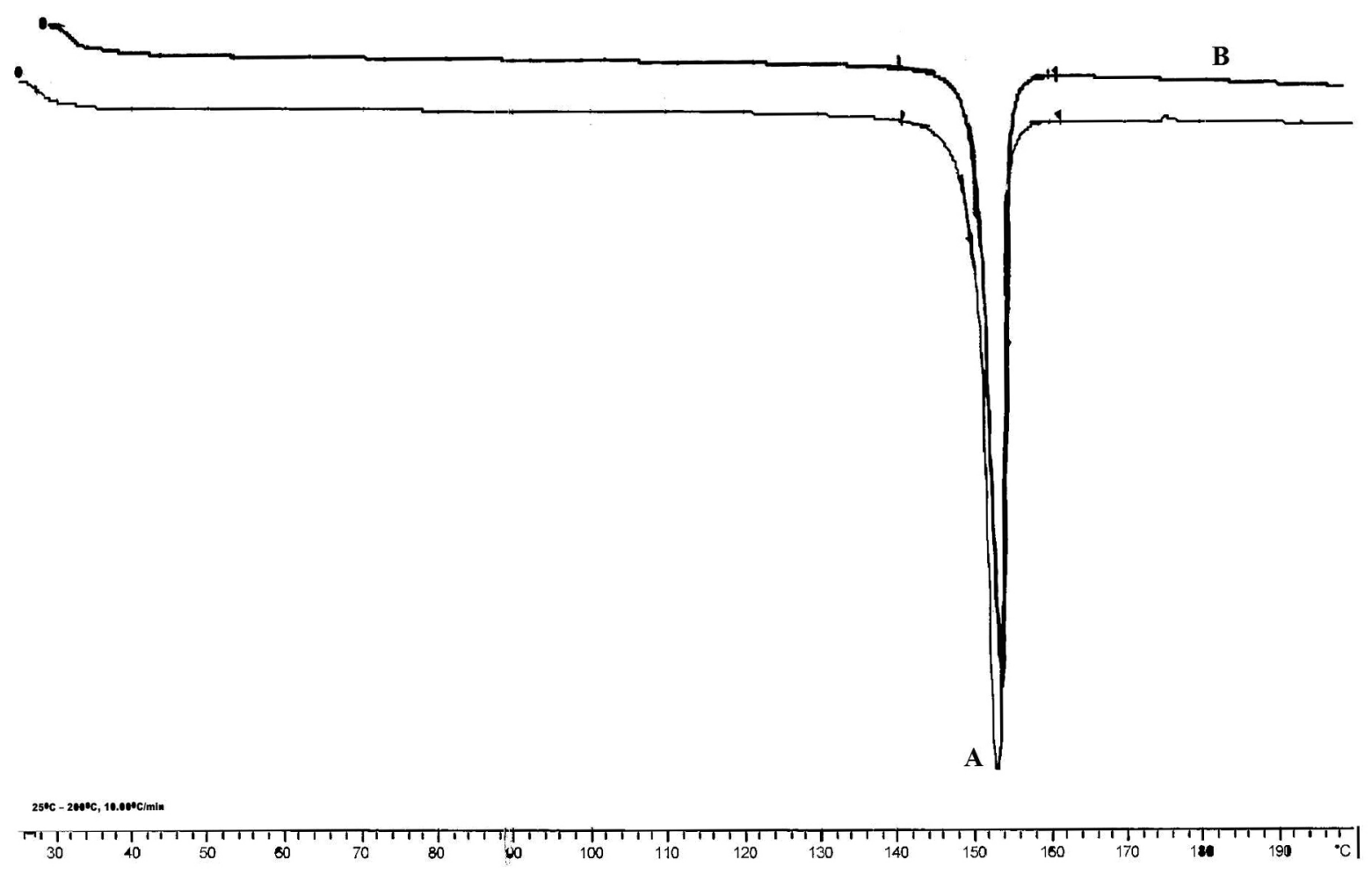

A - naproxen pure drug, B - naproxen agglomerates

FIGURE 1 - Differential scanning calorimetric thermograms of naproxen and agglomerates DSC chromatogram clearly shows that pure drug (A) and spherical agglomerate obtained (B) showed melting range of $148-158^{\circ} \mathrm{C}$ indicating that there was no chemical modification in the drug due to the method employed.

ates were identified in scanning electron microscopy. The pure naproxen was in the form of plate like particles as appeared in Figure 4. Where as naproxen agglomerates prepared were having clusters of plate shaped particles, which are not that spherical but irregular in shape as shown in Figure 3. Upon high magnification it was further observed that surfaces are not smooth and no liquid bridges found in between particles shown in Figure 4. Thus the produced clusters may not be spherical agglomerates, but bunches of plate like crystals. This cluster formation may be responsible for enhancement of flow property, packability and drug release rate as observed in our investigation.

\section{Surface topography}

Agglomerates obtained were moderately spherical in shape with circularity factor ranging between $0.891-0.912$ (1 Indicates the spherical shape).

\section{Micromeritic properties}

The micromeritic properties like bulk density, tapped density, angle of repose and Carr's index were determined and shown in Table I. The bulk and tapped densities of the spherical agglomerates were lower than the corresponding value of the pure sample, with the particle size and sphericity being higher. The lower density is likely to be related to the intraparticle porosity and reduced bulk density of the treated samples indicates a greater porosity within the agglomerated particles. Carr's index for agglomerates was found to be lower when compared to pure drug. This may be due to the formation of agglomerates. Fine particles having high surface to mass ratios are more cohesive than coarser particles, hence more influenced by gravitational force. Decreased values of Carr's index for agglomerates indicate better packability, and that they might be suitable for direct tabletting. Flow properties of the agglomerates were reflected by angle of repose. It was found that angle of repose of agglomerates were decreased when compared to pure naproxen. Such decreased value indicates improvement in flowability.

Lower densities of spherical agglomerates than the pure sample indicate better spherecity and porosity. Lower Carr's index for agglomerates makes their pack- 


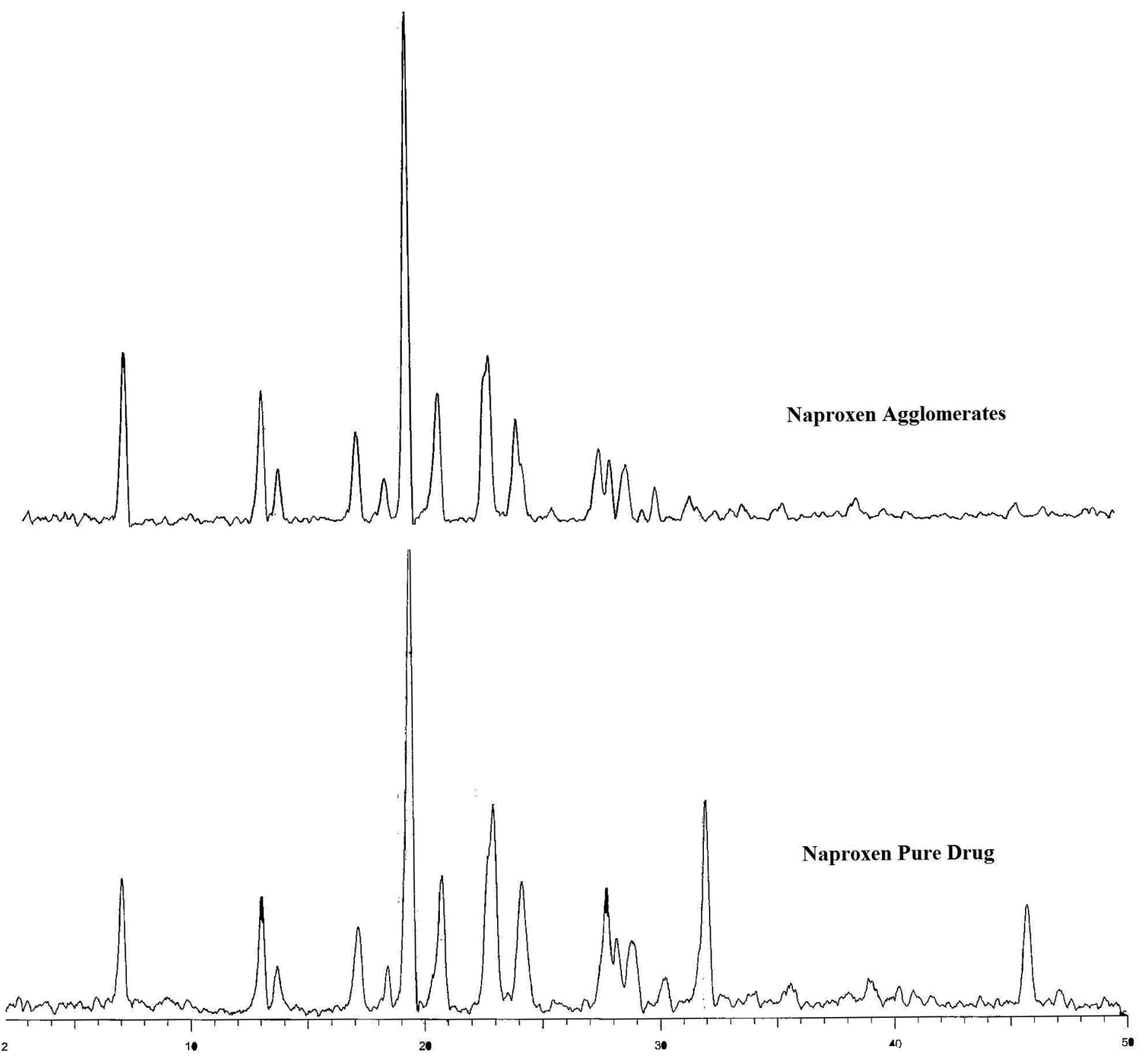

FIGURE 2 - X-Ray diffraction spectra of naproxen and agglomerates

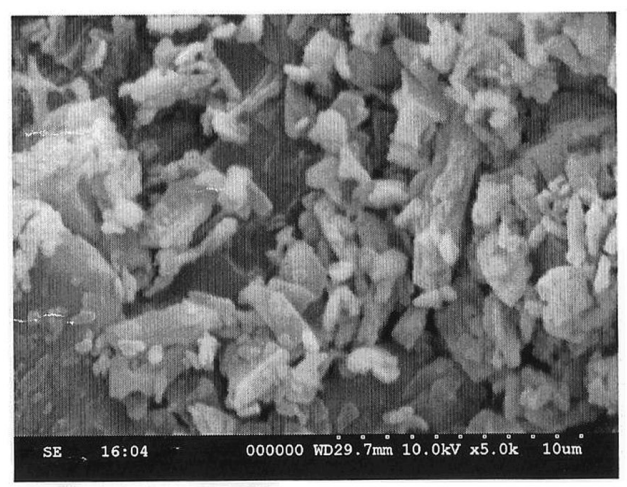

(A)

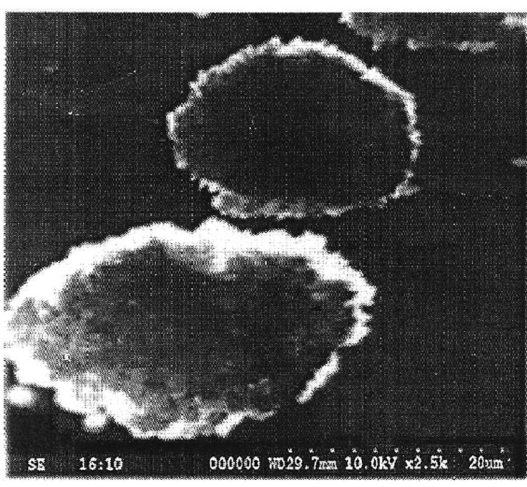

(B)

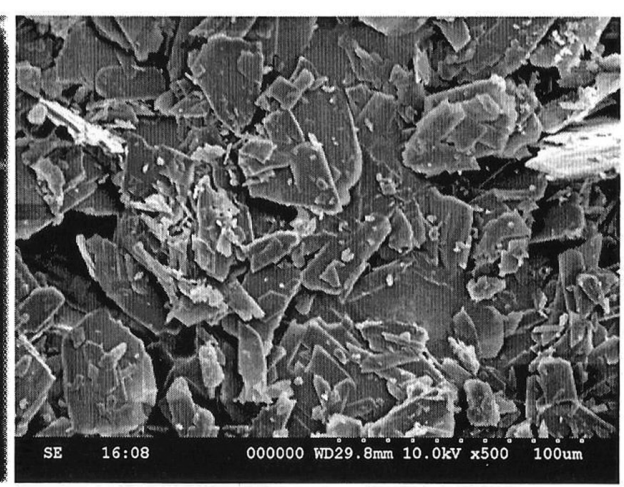

(C)

FIGURE 3 - SEM of A: naproxen pure drug, B: agglomerate, C: surface of the agglomerate. The powder was irregularly shaped (A) and spherical agglomerates were obtained after the successful completion of experiment (B). The surface of the spherical agglomerate $(\mathrm{C})$ shows that the minute particles of the drug have agglomerated to give a spherical shape. 
TABLE I- Micromeritic properties of naproxen pure drug and agglomerates

\begin{tabular}{lcc}
\hline Properties & Pure Drug & Agglomerates \\
\hline Particle size $(\mu \mathrm{m})$ & $5-10$ & $\begin{array}{c}830 \text { (Average } \\
\text { particle size) }\end{array}$ \\
Flow rate $(\mathrm{g} / \mathrm{s})$ & $5.42 \pm 1.87$ & $11.23 \pm 0.93$ \\
Angle of repose & $54 \pm 1.35$ & $46 \pm 0.79$ \\
Tapped density $(\mathrm{g} / \mathrm{mL})$ & $0.211 \pm 0.24$ & $0.349 \pm 0.14$ \\
Bulk density $(\mathrm{g} / \mathrm{mL})$ & $0.134 \pm 0.128$ & $0.237 \pm 0.43$ \\
Carr's index & 36.492 & 32.09 \\
Mechanical strength $(\%)$ & - & $0.974 \pm 1.37$ \\
\hline
\end{tabular}

Values are average of 3 determinations $(n=3)$

ability better, and might be suitable for direct tabletting. Flow properties of the agglomerates were reflected by angle of repose, and a lower value shows improvement in flowability.

\section{Crushing strength}

The crushing strength of agglomerates was in the range of 105-110 $\mathrm{g}$ and was unaffected by the process variables.

\section{Residual solvents concentration}

The results of residual solvent concentration in naproxen agglomerates reported in Table II. According to Guideline for residual solvents Q3C (International Conference on Harmonization of Technical Requirements For Registration of Pharmaceuticals For Human Use), acetone and dichloromethane are class 3 class 2 solvents respectively (solvents with low toxic potential and solvents should be limited), thus the limits of $5000 \mathrm{ppm}$ and $600 \mathrm{ppm}$ are acceptable without justification. The results obtained for acetone and dichloromethane are largely below the tolerated limits.

TABLE II- Residual solvent contents of naproxen agglomerates

\begin{tabular}{lcc}
\hline Residual solvent & $\begin{array}{c}\text { Concentration } \\
(\mathrm{ppm})\end{array}$ & $\begin{array}{c}\text { Concentration limit } \\
(\mathrm{ppm}) *\end{array}$ \\
\hline Water & $0.912 \pm 0.23 \%$ & - \\
Acetone (Class III) & $4.2036 \pm 1.458$ & 5000 \\
$\begin{array}{l}\text { Dichloromethane } \\
\text { (Class II) }\end{array}$ & $3.561 \pm 2.14$ & 600 \\
\hline
\end{tabular}

*As per ICH guide lines. Values are average of 3 determinations $(n=3)$
The residual solvent concentration of acetone and dichloromethane (solvents with low toxic potential and solvents should be limited), obtained were largely below the tolerated limits according to ICH guidelines and thus the agglomerates are acceptable

\section{Solubility studies}

Spherical agglomerates showed distinct solubility pattern in water and buffer ( $\mathrm{pH} 7.4$ phosphate). It was noted that solubility of spherical agglomerates increased when compared with pure drug as shown in Table III. But, it was found that the solubility of naproxen was more in buffer than water which can be owed to its poor water solubility in lower $\mathrm{pH}$.

TABLE III- Solubility Data of naproxen

\begin{tabular}{lcc}
\hline Solubility medium & Pure Drug & Agglomerates \\
\hline Water $(\% \mathrm{~W} / \mathrm{V})$ & $0.00586 \pm 1.031$ & $0.01795 \pm 0.93$ \\
7.4 Phosphate buffer & $3.94 \pm 0.18$ & $7.71 \pm 0.34$ \\
$(\% \mathrm{~W} / \mathrm{V})$ & & \\
\hline
\end{tabular}

Values are mean \pm standard deviation $(n=3)$.

Spherical agglomerates showed increased solubility in water and buffer ( $\mathrm{pH} 7.4$ phosphate) compared to pure drug. But, it was found that the solubility of naproxen was more in buffer than water which can be owed to its poor water solubility in lower $\mathrm{pH}$.

\section{Dissolution studies of agglomerates}

The dissolution rate of pure naproxen is less than that of naproxen agglomerates. The reason for faster dissolution is good wettability of the agglomerates. After applying one way analysis of variance (ANOVA) it has been observed that there was significant difference $(p<$ 0.05 ) between the dissolution profiles of agglomerates when compared to pure sample.

\section{In vivo evaluation of agglomerates}

Anti-inflammatory activity and ulcerogenic potential were carried out for pure naproxen and agglomerates. Table IV shows the results of paw edema and percentage inhibition of carrageenan-induced paw edema in rats treated with pure naproxen and naproxen agglomerates. An extremely significant $(\mathrm{p}<0.001)$ inhibition of carrageenan induced paw edema was observed in animals treated with naproxen agglomerates in comparison with control during the entire $3 \mathrm{~h}$ duration of the study, significant $(\mathrm{p}<0.05)$ in- 
TABLE IV- Anti-inflammatory activity of pure naproxen and naproxen agglomerates

\begin{tabular}{lcccc}
\hline Group & Treatment & Time $(\mathrm{h})$ & Paw volume mean & \% Inhibition \\
\hline Control & Water & 5 & 0.46 & --- \\
Standard & $25 \mathrm{mg} / \mathrm{kg}$ pure naproxen & 5 & $0.28 \pm 1.36$ & $39.13 \pm 2.16$ \\
Test & $25 \mathrm{mg} / \mathrm{kg}$ naproxen agglomerates & 5 & $0.16 \pm 2.57$ & $65.21 \pm 2.85$ \\
\hline
\end{tabular}

Values are mean \pm standard deviation $(n=3)$.

hibition of carrageenan induced paw edema was observed in animals treated with naproxen agglomerates in comparison with naproxen pure drug during the entire $5 \mathrm{~h}$ duration of the study. This may be due to increased dissolution of agglomerates over pure drug, leading to better absorption and onset of action of drug. There was no drastic change in gastric $\mathrm{pH}$ when treated with naproxen and naproxen agglomerates. No ulcers were observed and the colour of stomach was normal.

Paw edema and percentage inhibition of carrageenan-induced paw edema in rats show a significant inhibition $(\mathrm{p}<0.05)$ in animals treated with naproxen agglomerates due to increased dissolution of agglomerates over pure drug, leading to better absorption and onset of action of drug. Hence, agglomerates showed better anti-inflammatory activity over the pure drug.

Therefore, the results of the in vivo studies clearly demonstrate that the naproxen agglomerates showed better anti-inflammatory activity over the pure drug, thus confirming the better therapeutic efficacy of the naproxen agglomerates.

\section{CONCLUSION}

Naproxen agglomerates that were prepared by simple spherical crystallization technique exhibited improved micromeritic properties and dissolution rate. DSC and XRD study showed that there is no change in the crystal structure and polymorphism was not occurred. Due to the significant improvement of micromeritic properties, this technique may be used for formulation of naproxen tablets by direct compression method. The agglomerates were found to be having better anti-inflammatory activity in the rats when compared to pure drug due to improved solubility.

\section{ACKNOWLEDGEMENTS}

The authors are thankful to M/S Divis Labs, Hyderabad, India for the gift sample of Naproxen. We also thank the Quality Assurance Deputy Manager, Macleods Pharmaceuticals, Vapi, Gujarat for gas chromatographic analysis.

\section{REFERENCES}

AULTON, M. E.. Aulton's Pharmaceutics the design and manufacture of medicine. 3.ed. London: Churchill Livingstone Elsevier, 2007. p.355-357.

DI MARTINO, P.; BARTHELEMY, C.; PIVA, F.; JOIRIS, E.; PALMIERI,G.F.; MARTELLI, S. Improved dissolution behavior of fenbufen by spherical crystallization. Drug Dev. Ind. Pharm., v.25, n.10, p.1073-1081, 1999.

DI MARTINO, P.; DI CRISTOFARO, R.; BARTHELEMY, C.; JOIRIS, E.; PALMIERI FILIPPO, G.; SANTE, M. Improved compression properties of propyphenazone spherical crystals. Int. J. Pharm., v.197, n.1-2, p.95-106, 2000.

INDIAN PHARMACOPOEIA. The Indian Pharmacopoeia commission. 6.ed. PA: Ghaziabad, 2010. v.3, p.1754-1758.

KULKARNI, P.K.; NAGAVI, B.G. Spherical crystallization. Ind. J. Pharm. Educ., v.36, n.5, p.66-73, 2002.

KULKARNI, S.K. Hand book of experimental pharmacology. 3.ed. New Delhi: Vallabh Prakashan, 2002. 149 p.

LICHTENBERGER, M.; ROMERO, J.J.; DIAL, E.J.; MOORE, J.E. Naproxen-PC: A GI safe and highly effective antiinflammatory. Inflammopharmacology, v.17, n.1, p.1-5, 2009.

MAGHSOODI, M.; HASSAN-ZADEH, D.; BAZEGARJALALI, M. Improved compaction and packing properties of naproxen agglomerated crystals obtained by spherical crystallization technique. Drug Dev. Ind. Pharm., v.33, n.1, p.1216-1224, 2007.

NOCENT, M.; BERTOCCHI, L.; ESPITALIER, F.; BARON, M.; COURRAZE, G. Definition of a solvent system for spherical crystallization of salbutamol sulfate by quasiemulsion solvent diffusion (QESD) method. J. Pharm. Sci., v.90, n.10, p.1620-1627, 2001. 
PARADKAR, A.R.; PAWAR, A.P.; CHORDIYA, J.K.; PATIL, V.B.; KETKAR, A.R. Spherical crystallization of celecoxib. Drug Dev. Ind. Pharm, v.28, n.10, p.1213-1220, 2002.

RAO, C.M.; RAMESH, K.V.; BIARY, K.L.; KULKARNI, D.R. Zinc complexes of NSAIDS abolish gastric ulceration propensity of parent drugs. Indian Drugs, v.28, n.2, p.6467, 1990.

SANO, A.; KURIKI, T.; HANDA, T.; TAKEUCHI, H.; KAWASHIMA, Y. Particle design of tolbutamide in the presence of soluble polymer or surfactant by spherical crystallization technique: improvement of dissolution rate. J. Pharm. Sci., v.76, n.6, p.471-474, 1999.
SANO, A.; KURIKI, T.; KAWASHIMA, Y.; TAKEUCHI, H.; NIWA, T.; HINO, T. Particle design of tolbutamide by the spherical crystallization technique. III. Micromeritic properties and dissolution rate of tolbutamide spherical agglomerates prepared by the quasi-emulsion solvent diffusion method and the solvent change method. Chem. Pharm. Bull., v.38, n.3, p.733-739, 1990.

VEERAPUR, V.P.; BADIGER, A.M.; JOSHI, S.D.; NAYAK, V.P.; SHASTRY, C.S. Antiulcerogenic activity of various extracts of dodonaea viscosa (L) Jacq.Leaves. Ind. J. Pharm. Sci., v.66, n.4, p.407-411, 2004.

Received for publication on $17^{\text {th }}$ September 2011 Accepted for publication on $23^{\text {th }}$ July 2012 